\title{
Prioritization of Water Conservation Practices Adopted By Farmers in Haryana and Rajasthan
}

\author{
Jitendra Kumar Chauhan ${ }^{1 *}$, Sitaram Bishnoi ${ }^{2}$, Satyapriya ${ }^{2}$ and H. R. Meena ${ }^{3}$ \\ ${ }^{1}$ Agricultue Extension, College of Post Graduate Studies in \\ Agricultural Sciences, Umiam, Meghalya (CAU, Imphal, Manipur), India \\ ${ }^{2}$ ICAR-IARI, New Delhi, India \\ ${ }^{3}$ ICAR-NDRI, Karnal, India \\ *Corresponding author
}

\section{A B S T R A C T}

\begin{tabular}{l} 
Ke y w or d s \\
$\begin{array}{l}\text { Adoption, } \\
\text { Prioritization, } \\
\text { Water Conservation }\end{array}$ \\
\hline Article Info \\
\hline $\begin{array}{l}\text { Accepted: } \\
\text { 12 December } 2020 \\
\text { Available Online: } \\
\text { 10 January 2021 }\end{array}$ \\
\hline
\end{tabular}

\section{Keywords}

Adoption,

Prioritization,

Water Conservation

ary 202
The relative importance of water towards food production as well as human survival cannot be changed very easily, although reduced and balanced. A huge interest of researchers and policy makers in vested in studying the sustainable use of water and ensure its economical utilization in agriculture and food sector. For the purpose of prioritization of water conservation practices in study area an open ended schedule was developed. In the preliminary survey the respondents were asked to list out the water conservation practices in the study area. A final screening and sorting out of the water conservation practices were undertaken depending on their frequency of occurrence. The prioritization of water conservation practices was done by using Garret ranking method in which the water conservation practices like "Lifesaving irrigation from water harvesting structure" was given first rank and garret score was 81.14 in Bikaner district as well as in Sonipat and Hisar district "Lifesaving irrigation if available" was given first rank and garret score was 86.18. It would be a useful tool for increasing water use efficiency for crop production, which could be achieved by educating the farmers about the negative consequences of high consumptive water use.

\section{Introduction}

In past few years, assessing the global, ecological and environmental sustainability has got wider recognition and attention worldwide. The rising global water scarcity has become a catastrophic issue having a call for action by governments, policy-makers, water managers and water users among private, public and non-governmental organizations in the issues related to environmental and sustainable use of natural resources. From several studies we can infer that four billion population across the world face the huge problem of water scarcity (Mekonnen and Hoekstra, 2011). After assessment the indicators of water sustainability across different sectors of economy at global level it was found that, the largest share of freshwater is used in 
production of food at global level. About 86 percent of the total freshwater resources are consumed for the food production resources in the world (IWMI, 2007). Thus realizing the relative importance of water towards food production as well as human survival cannot be changed very easily, although reduced and balanced. A huge interest of researchers and policy makers in vested in studying the sustainable use of water and ensure its economical utilization in agriculture and food sector. Freshwater extraction in at global level has increased by nearly seven-folds in the previous century (Gleick, 2000). Change in diet preferences as per growing population could increase the water withdrawals in the upcoming decades (Rosegrant and Ringler, 2000). Consumptive use of water denotes to the amount of water would be longer available after its immediate use. The agriculture consumes about 85 percent of the global freshwater at present time (Shiklomanov, 2000; Hoekstra and Chapagain, 2007). The findings of previous studies about water use focused on water withdrawals for different sectors of the economy. There are very few studies of global water consumption (evaporative use of water).

Farmers are using a large proportion of imported nutrients, which are likely to load the soil with surplus nutrients. These surpluses amount may affect crop quality and water quality, because the nutrients may become available for plant uptake or leach down. In the long term, best management practices would not be enough to reduce the nutrient imbalances, and major changes in nutrient management will be needed to supplement better nutrient and water use efficiency. Efficient management changes must meet the twin goals of improving the long term sustainability of nutrient management, while maintaining the economic health and viability of the dairy business. The finding of Sathiadhas et al., (2003) highlighted the salinity of soil and water as major constraints faced by the dairy farmers. Only the availability of land was not enough for it. Extensive cultivation of saline tolerant perennial fodder could be helpful in overcoming this problem. Agriculture being a low priority area in coastal agro ecosystem, the value of farm wastage is not properly appreciated, instead it is considered as a major source of environmental pollution. Succlent fodder should be grown to utilize wasted resource.

\section{Materials and Methods}

The present study was conducted in two agro climatic zones i.e. Trans- Gangetic plain region (consisting Punjab, Haryana, Delhi and Chandigarh states) and western dry (consisting Rajasthan state) region. In TransGangetic plain region Haryana states and in western dry region Rajasthan state were selected purposively. Further from Haryana state Hisar and Sonipat district and Bikaner district of Rajasthan were selected randomly. The Sonipat and Hisar were selected randomly from Eastern Haryana and western Haryana region and Bikaner district of Rajasthan state. Four blocks were also selected randomly from each districts constituting its total number of 12. Each cluster of village consists of 3-4 nearby villages from the selected block in the district of the study area. Thus, 4 clusters of villages one from each blocks were selected, constituting its total number to 12 clusters. From each cluster of villages, 18 respondents were selected in this way a total of 216 respondents were selected from 12 cluster of villages for the study. For the purpose of prioritization of water conservation practices in study area an open ended schedule was developed. In the preliminary survey the respondents were asked to list out the water conservation practices in the study area. A 
final screening and sorting out of the water conservation practices were undertaken depending on their frequency of occurrence. The most frequent water conservation practices were selected for the purpose of their final prioritization by means of using Garret Ranking Technique. Then in the actual data collection the respondents were asked to rank each of the factors relevant to them according to the degree of importance as perceived by them. As all the items may not be ranked by all the respondents the method of combining of incomplete order of merit ratings as suggested by Garret (1981) will be followed. The formula for percent position as suggested by Garret (1981) is

Percent position $=100(\mathrm{R}-0.5) \div \mathrm{N}$

Where $\mathrm{R}$ is the rank of the individual item in the series and $\mathrm{N}$ is the number of individual items ranked. Scores for each of the factors after transmutation of orders of merit as per Garret (1981) will be found out. To obtain the final order of merit, the scores for all the respondents for each of the factor will be summated and the mean value will be calculated. In finding out the mean values, the sum of the scores for each item will be divided by its frequency of responses.

\section{Results and Discussion}

A perusal of Table 1 reveals that the mean age of respondents was found 40.15 years, while minimum age was 25 years. There is wide variation in the experience of respondents in dairy farming which varied between 2 to 16 years and the mean experience in dairying was found 7.41 years which shows the sound results could be drawn from the study. The mean herd size in the study was 7.33, and average annual income was` 83365 which reflects that farmers are adaptive to change or adopt new water conservation practices and apt enough to form any perception about the water use.
Water conservation practices adopted by farmers were taken in which they were asked to rank the practices which farmer would prefer to increase the water use efficiency in the dairy farming.

All the listed factors were ranked by the farmers, and after that method of combining of incomplete order of merit ranking was used in the study accordingly as suggested by Garrett (1969).

The data were analyzed by using Garrett's ranking technique and suitable inferences were drawn. The percent position was calculated for the ranks in their corresponding Garreett's table value as given below for the Bikaner district.

The water conservation practices adopted by farmers were identified from secondary sources and preliminary survey. In which, Garreet Values of Table were incorporated and subsequently Garrett scores for all 11 practices were identified (Table 2). Practices such as lifesaving irrigation from water harvesting structure, conservation of soil moisture, construction of water harvesting structure under MNREGA, sowing of barley and fodder crop using poor quality water, Harvest for fodder if damage will be severe, In-situ conservation of moisture, use of sprinkler/micro pressurized irrigation method, alternate furrow irrigation, mulching the crop rows, reduction of area under wheat and allocate area under mustard/barley/gram/ isabgol and rain water harvesting, recycling through farm ponds were identified and responses were taken.

Lifesaving irrigation from water harvesting structure (WCP1) was the practice which was the first preference of the respondents and thus ranked one with Garrett score of 81.14, subsequently mulching crop rows(WCP9) was ranked second, Alternate furrow 
irrigation(WCP8) was ranked third with Garrett score of 80.18 (Table 3). For each water conservation practice, after obtaining the response of farmers as 1 to 11 ranks, Total score was calculated after multiplying the frequency of response in each category of ranking with the water conservation practice. Maximum Garrett score was 81.14 which was ranked one and least Garrett score was 78.28 which was ranked last (Table 3).

Among the least preferred practices, rain water harvesting, recycling through farm ponds(WCP11) with Garrett score of 78.28, use of sprinkler/micro pressurized irrigation method(WCP7) with Garrett score of 78.63 and reduction area under wheat and allocate area under mustard/barley/gram/ isabgol (WCP10) with Garrett score of 78.65 were ranked 11,10 and 9 respectively (Table 3 ).

\section{Water Conservation Practices (WCP) identified in Haryana}

Lifesaving irrigation from water harvesting structure (WCP1) was the practice which was the first preference of the farmers and thus ranked one with Garrett score of 81.14, subsequently mulching crop rows(WCP9) was ranked second, Alternate furrow irrigation(WCP8) was ranked third with a Garrett score of 80.18. Among the least preferred practices, rain water harvesting, recycling through farm ponds(WCP11) with Garrett score of 78.28, use of sprinkler/micro pressurized irrigation method(WCP7) with Garrett score of 78.63 and reduction area under wheat and allocate area under mustard/barley/gram/ isabgol (WCP10) with Garrett score of 78.65 were ranked 11, 10 and 9 respectively.

Table.1 Representation of summary statistics of socio- economic parameters

\begin{tabular}{|c|l|c|c|c|c|c|}
\hline Sr. No. & Variable & Obs & Mean & \multicolumn{2}{|c|}{$\begin{array}{c}\text { Std. Dev. } \\
\text { Min }\end{array}$} & Max \\
\hline $\mathbf{1}$ & Age (in years) & 216 & 40.15 & 10.0277 & 25 & 62 \\
\hline $\mathbf{2}$ & Experience in Dairying (in years) & 216 & 7.41 & 3.657632 & 2 & 16 \\
\hline $\mathbf{3}$ & Herd Size (No.) & 216 & 7.33 & 2.722858 & 3 & 14 \\
\hline $\mathbf{4}$ & Annual Income () & 216 & 83365.74 & 27521.84 & 40000 & 145000 \\
\hline
\end{tabular}

Table.2 Percent Position and Garret Score of Water Conservation Practices (WCP) identified in Bikaner

\begin{tabular}{|c|c|c|}
\hline \multicolumn{3}{|c|}{ Percent Position } \\
\hline Rank & $\mathbf{1 0 0}(\mathbf{R i j}-\mathbf{0 . 5}) / \mathbf{N}_{\mathbf{j}}$ & Garret Value \\
\hline $\mathbf{1}$ & 0.69 & 94 \\
\hline $\mathbf{2}$ & 2.08 & 88 \\
\hline $\mathbf{3}$ & 3.47 & 85 \\
\hline $\mathbf{4}$ & 4.86 & 82 \\
\hline $\mathbf{5}$ & 6.25 & 79 \\
\hline $\mathbf{6}$ & 7.64 & 78 \\
\hline $\mathbf{7}$ & 9.03 & 76 \\
\hline $\mathbf{8}$ & 10.42 & 75 \\
\hline $\mathbf{9}$ & 11.81 & 74 \\
\hline $\mathbf{1 0}$ & 13.19 & 72 \\
\hline $\mathbf{1 1}$ & 14.58 & 70 \\
\hline
\end{tabular}


Table.3 Ranking of Water Conservation Practices (WCP) in Bikaner

\begin{tabular}{|c|l|c|c|c|}
\hline Sr. No. & Water Conservation Practices (WCP) & $\begin{array}{c}\text { Total } \\
\text { Score }\end{array}$ & $\begin{array}{c}\text { Garret } \\
\text { Score }\end{array}$ & Rank \\
\hline $\mathbf{1 .}$ & Lifesaving irrigation from water harvesting structure. (WCP1) & 5842 & 81.14 & I \\
\hline $\mathbf{2 .}$ & Conserve soil moisture (WCP2) & 5695 & 79.10 & VI \\
\hline $\mathbf{3 .}$ & Water harvesting structure constructed under MNREGA(WCP3) & 5688 & 79.00 & VII \\
\hline $\mathbf{4 .}$ & Sowing of barley and fodder crop using poor quality water(WCP4) & 5741 & 79.74 & IV \\
\hline $\mathbf{5 .}$ & If damage will be severe, Harvest for fodder(WCP5) & 5676 & 78.83 & VIII \\
\hline $\mathbf{6 .}$ & In-situ moisture conservation (WCP6) & 5703 & 79.21 & V \\
\hline $\mathbf{7 .}$ & Use sprinkler/micro pressurized irrigation method (WCP7) & 5661 & 78.63 & X \\
\hline $\mathbf{8 .}$ & Alternate furrow irrigation(WCP8) & 5773 & 80.18 & III \\
\hline 9. & Mulching crop rows(WCP9) & 5778 & 80.25 & II \\
\hline $\mathbf{1 0 .}$ & $\begin{array}{l}\text { Reduce area under wheat and allocate area under mustard/barley/gram/ } \\
\text { isabgol (WCP10) }\end{array}$ & 5663 & 78.65 & IX \\
\hline $\mathbf{1 1 .}$ & Rain water harvesting, recycling through farm ponds (WCP11) & 5636 & 78.28 & XI \\
\hline
\end{tabular}

Table.4 Percent Position and Garret Score for Water Conservation Practices (WCP) identified in Haryana

\begin{tabular}{|c|c|c|}
\hline \multicolumn{3}{|c|}{ Percent Position } \\
\hline Rank & $\mathbf{1 0 0 ( \text { Rij-0.5)/Nj }}$ & Garret Value \\
\hline $\mathbf{1}$ & 0.35 & 97 \\
\hline $\mathbf{2}$ & 1.04 & 92 \\
\hline $\mathbf{3}$ & 1.74 & 89 \\
\hline $\mathbf{4}$ & 2.43 & 88 \\
\hline $\mathbf{5}$ & 3.13 & 85 \\
\hline $\mathbf{6}$ & 3.82 & 84 \\
\hline $\mathbf{7}$ & 4.51 & 82 \\
\hline $\mathbf{8}$ & 5.21 & 81 \\
\hline $\mathbf{9}$ & 5.90 & 80 \\
\hline $\mathbf{1 0}$ & 6.60 & 79 \\
\hline
\end{tabular}

Table.5 Ranking of Water Conservation Practices (WCP) in Haryana

\begin{tabular}{|c|l|c|c|c|}
\hline Sr. No. & Water Conservation Practices (WCP) & $\begin{array}{c}\text { Total } \\
\text { Score }\end{array}$ & $\begin{array}{c}\text { Garret } \\
\text { Score }\end{array}$ & Rank \\
\hline $\mathbf{1 .}$ & Straw mulching in between rows (WCP1) & 12348 & 85.75 & V \\
\hline $\mathbf{2 .}$ & Make ridge and furrow for rain water harvesting (WCP2) & 12259 & 85.13 & IX \\
\hline $\mathbf{3 .}$ & Remove every third row for green fodder (WCP3) & 12306 & 85.46 & VII \\
\hline $\mathbf{4 .}$ & Lifesaving irrigation if available (WCP4) & 12411 & 86.19 & I \\
\hline $\mathbf{5 .}$ & Change in cropping system (WCP5) & 12390 & 86.04 & II \\
\hline $\mathbf{6 .}$ & Micro-drip irrigation (WCP6) & 12269 & 85.20 & X \\
\hline $\mathbf{7 .}$ & Avoid irrigation during hot hours (WCP7) & 12291 & 85.35 & VIII \\
\hline $\mathbf{8 .}$ & Irrigation with poor quality waters (WCP8) & 12351 & 85.77 & IV \\
\hline $\mathbf{9 .}$ & Limited ground water use, prefer lifesaving irrigation (WCP9) & 12339 & 85.69 & VI \\
\hline $\mathbf{1 0 .}$ & Laser land leveling (WCP10) & 12378 & 85.96 & III \\
\hline
\end{tabular}


For each water conservation practice, after obtaining the response of farmers as 1 to 10 ranks, Total score was calculated after multiplying the frequency of response in each category of ranking with the water conservation practice. Maximum Garrett score was 86.19 which was ranked one and least Garrett score was 85.20 which was ranked last (Table 5)

\section{Water Conservation Practices (WCP) identified in Haryana}

Lifesaving irrigation if available (WCP4) was the practice which was the first preference of the farmers and thus Ranked 1with Garrett score of 86.19, subsequently Change in cropping system (WCP5) was ranked second with Garrett score of 86.04 and Laser land leveling (WCP10)was ranked third with Garrett score of 85.96.

Among the least preferred practices, Microdrip irrigation (WCP6) with Garrett score of 85.20, Making of ridge and furrow for rain water harvesting (WCP2) with Garrett score of 85.13 and reduction area under wheat and Avoid irrigation during hot hours (WCP7) with Garrett score of 85.36 were ranked 10, 9 and 8 respective

In conclusion the majority $(53.24 \%)$ of the respondents belonged to middle age category with their age in range of 36 to 50 years followed by the category of young age $(<35$ years) and old age (>50 yrs) which accounts for 28.24 and 18.52 per cent, respectively.

It was also observed that 44.44 per cent of the farmers had medium level of experience in farming followed by low (34.26\%) and high $(21.30 \%)$ levels of experience in farming. The water conservation practices such as lifesaving irrigation from water harvesting structure, conservation of soil moisture, construction of water harvesting structure under MNREGA, sowing of barley and fodder crop using poor quality water, Harvest for fodder if damage will be severe, In-situ conservation of moisture, use of sprinkler/micro pressurized irrigation method, alternate furrow irrigation etc. could be the most prioritized and preferred by the farmers. Govt incentive could be an option to promote it among the farmers.

\section{References}

Gleick, P. H. (2000). A look at twenty-first century water resources development. Water international, 25(1): 127-138.

IWMI. (2007). Water for Food, Water for Life: a Comprehensive Assessment of Water Management in Agriculture. International Water Management Institute. Earthscan, London, UK.

Mekonnen, M. M., and A. Y. Hoekstra. (2011). National water footprint accounts: The green, blue and grey water footprint of production and consumption. Value of Water Res. Rep. Ser. No. 50. UNESCO-IHE, Delft, the Netherlands.

Rosegrant, M. W., \&Ringler, C. (2000).Impact on food security and rural development of transferring water out of agriculture. Water Policy, 1(6): 567-586.

Shiklomanov, I.A. (2000). Appraisal and Assessment of World Water Resources, Water International 25(1): 11- 32.

Sathiadhas, R., Noble D, Sheela Immanuel, Sindhu Sadanandan. (2003). Adoption level of scientific dairy farming practices by IVLP farmers in the coastal agro ecosystem of Kerala.Indian Journal of Social Research,44 (3): 243250. 


\section{How to cite this article:}

Jitendra Kumar Chauhan, Sitaram Bishnoi, Satyapriya and Meena, H. R. 2021. Prioritization of Water Conservation Practices Adopted By Farmers in Haryana and Rajasthan. Int.J.Curr.Microbiol.App.Sci. 10(01): 1865-1871. doi: https://doi.org/10.20546/ijcmas.2021.1001.218 